\title{
Sydney Clouts's poetry: Looking inwards, looking outwards
}

\section{Michael Chapman}

\section{Sydney Clouts's poetry: Looking inwards, looking outwards}

Intimate Lightning, by Dan Wylie, presents a detailed account and evaluation of Sydney Clouts's poetry as phenomenologically driven: a poetry that invites readers to look inwards to the "speck and the fleck" of things in the natural world. At the same time, Wylie posits that Clouts is the finest poet of his generation in South Africa of the 1960s. In this article, I acknowledge Wylie's engagement with the poetry while I question whether the somewhat relentless focus inwards is not too neglectful of those poems in which Clouts looks outwards to human interaction in the world. Such poems of abbreviated narrative, some of which I analyse in the course of my argument, suggest that looking outwards is necessary, at least, to consider Wylie's claim that Clouts's poetry is yet to receive its wider and just recognition. Given that Wylie offers little, if any, substantiation of Clouts's standing as a poet among his peers, I move to a 'summary' perspective on Clouts in relation to what, I contend, is a rich and various poetry scene in 1960s South Africa. This leads me to the conclusion that the question of whether Clouts is the finest poet of his generation is not perhaps the question best pursued in Intimate Lightning. Where Wylie's study succeeds is in reminding us that Clouts is a poet quite unlike any other we will encounter. Keywords: Sydney Clouts, Dan Wylie, sensory perception, human interaction, South African poetry in the 1960s.

\section{The "speck and the fleck"}

Intimate Lightning. Sydney Clouts: Poet — the study by Dan Wylie published in 2019, which is my starting point in this article-seeks to rescue Clouts from what Wylie regards as the poet's relative and undeserved obscurity. Wylie offers a detailed and illuminating engagement with the poetry in relation to key philosophical and artistic influences upon Clouts's poetic practice. The corollary point - that, "at his best, Clouts is the finest South African poet of his generation" (257) - is given insufficient substantiation to convince me, at least, that Clouts will command a more prominent place than he already does in a wider literary landscape. I acknowledge Wylie's attention to Clouts's poetry as phenomenologically driven: a poetry which, through sensory perception, wants to enter the "thingbeddedness" of things. I go on to suggest, however, that in his somewhat relentless focus on Clouts's poems of the "speck and the fleck" - on poems of close attention to details of nature, to colour, and light-Wylie neglects to give due consideration to those poems in which Clouts attaches the objects in his surroundings to a narrative, however abbreviated, of human interaction in the world. After looking inwards to Clouts's poems, I depart from Wylie to look outwards, as it were, as a prelude to the final section of argument in which, in summary, I attempt to convey something of the literary output and temper of the generation of the 1960s in South Africa. The 1960s is the decade in which most of Clouts's poems were written and which saw the publication of One Life in 1966, the only collection of poetry to appear in the poet's lifetime (the posthumously published Collected Poems appeared in 1984).

Born in Cape Town in 1926, Sydney Clouts attended the South African College School (SACS) and, after serving in the South African Signal Corp. for the last two years of the Second World War, he pursued a BA in 1950 at the University of Cape Town. He worked as an editor in the International Press Agency in Cape Town until 1961 when, at his wife's urging, he moved with Margery and their three sons to England, a country, as Clouts put it, "whose mediocrity displays itself" ("A country whose mediocrity ..." n. p.). Together with Margery, he established a 'cottage' literary agency prior to his return to South Africa in 1969 for two years as a research fellow at the Institute for the Study of English in Africa at Rhodes University. While in Grahamstown, he completed a master's

Michael Chapman is a researcher-in-residence in the Department of Media, Language, and Communication, Faculty of Arts and Design at the Durban University of Technology, Durban, South Africa. He remains a professor emeritus of the University of KwaZulu-Natal, Durban, South Africa. Email: michaelc3@dut.ac.za

(D) https://orcid.org/0000-0002-1299-8336

D0l: https://doi.org/10.17159/tl.v58i2.9003

DATES:

Submitted: 12 October; Accepted: 10 April 2021; Published: 10 September 2021 
thesis on the South African poets Thomas Pringle, Francis Carey Slater, and Roy Campbell. At the invitation of the British Council, he visited South Africa once more, in 1974, on a reading and lecturing tour of universities and schools. He died in England in 1982.

During his residency at the Institute, Ruth Harnett and Professor Guy Butler (both of the English Department, Rhodes University) recognised Clouts's talent and persuaded a publisher to invest in his poetry. One Life won both the Olive Schreiner and the Ingrid Jonker prizes for poetry while a 1984 special edition of the Grahamstown-based journal, English in Africa, is devoted to Clouts and includes the considerations of Harnett and Butler. With Clouts's holographic draft poems and other papers housed at the then National English Literary Museum (NELM) in Grahamstown, Wylie draws extensively on previously unpublished material, both poems and correspondence.

In his correspondence, especially with Butler, Clouts offers keen insight into what Harold Bloom referred to as the "anxiety of influence" that can be felt quite intensely by a poet outside of the Western mainstream: how within the traces of prior achievements, does the poet reclaim new possibilities of invention? As Clouts put it: "I've felt for some time rather set against the tradition because I think it's a tradition of anxiety-the European tradition of anxiety, the American-European, the Anglo-American, the European-American tradition of anxiety, which of course we have too" ("Sydney Clouts speaking about his poetry, $1 \& 2$ " 9).

Is the solution to look to 'Africa'? Clouts continues: “[...] one must be careful here, because there's quite a lot of humbug spoken about the effect of Africa upon art, or about what the African, the Black African, might do in contradistinction to what the white man might do in poetry. [...] But [the task of the poet] is to see what words can do" (9). As Wylie puts it in his study, Clouts sought to "transcend the time-bound specifics of culture" (15). Yet time-bound specifics refused to be entirely erased. This is evident in Clouts at his best, as in "Residuum":

Open, Open.

Enter the quick grain: everything is first.

I am in the dewfall ...

"History

surprise us!" is one petition.

("Residuum", Collected Poems 79, double spacing in the original)

It is also evident in Clouts at his worst, as in his "Hotknife" poems, which display a 'colonial' South Africanness that confirms all the white baas and madam's race and class stereotypes. Speaking in Clouts's rendition of 'Kaaps' ("Nellie newer/tol' me she was married sir"), the 'Coloured' character, Hotknife, is hot to knife, he is a drunkard, a fornicator, and a wheedler of any white person from whom he hopes to extract influence or cash. Wylie, in my opinion, grants too much attention to the "Hotknife" poems (40-6).

Showing less subscription to colonial dependency, Clouts departs from a motif in South African poetry of the 1950s - the decline of the West - to embed Greece and Rome (as Wylie notes) in "imperial violence", not only in "cultural richness" (178), while his poems of $16^{\text {th }}$-century Portuguese discovery transmute the voyage around the Cape to analogical dimension:

Canary Islands, brightly;

Bojador, in darkness

darkness

esperança!

Rounding the Cape, the sodden

wooden grumble of the wheel. ("The discovery", Collected Poems 73)

To quote Clouts: "[This poem] suggests to me something like the voyage of the spirit, but also the discovery of the Cape [...] an imagery resonant of voyage, of discovery, of being as part of being" (qtd in Harnett 130).

My cultural and historical reference notwithstanding, Wylie, as I have suggested, devotes less attention to Clouts in history, and more to Clouts in perception. How, in the poem, to catch the thisness of this, or the thingness 
of the thing? The study accompanies Clouts to coastlines, mountains, and animal kingdoms; to affinities not only with other poets but also with visual artists (Mondrian; Cézanne); and into philosophies of being in Socrates, in Heraclitian fire, Traherne's bright angels, Heidegger's 'dwelling', and particularly in Maurice Merleau-Ponty's phenomenology (238-43): "a spontaneity which accomplishes what appeared to be impossible when we observed only the separate elements, a spontaneity which gathers together the plurality of monads, past and present, nature and culture, into one sole cloth" (Barbaras 48 qtd in Wylie 242). This, Wylie suggests, is "precisely Clouts's ambition" (242) while Wylie's parallel ambition is to turn the wider reference inwards to the service of the poetry; 'authorities' are integrated into the 'one life' of the poem. Clouts's creatures, animals, and birds all "preserve an instinctual integrity, impenetrable and enviable" (114) like Coleridge's "Starlings in vast flights", it being possible that Clouts, "perhaps unconsciously, derived the title of his single published collection, One Life, from Coleridge's poem, 'The Eolian harp'? In the latter the music of the wind, 'like birds of Paradise [...] hovering on untam'd wing', exemplifies 'the one Life within us and abroad/Which meets all motion and becomes its soul"' (119). Or, as Clouts phrased it less in the romantic idiom, more in the idiom of T. S. Eliot's (modernist) impersonality of the 'made' artefact: "The imagination disestablishes its own constructions continually" ("Notes for poetry" 37 ). ${ }^{1}$

Clouts might have said the same of the aphoristic "Residuum", to which I have already referred, albeit briefly: My tradition is dew on a shrub.

One word is too many; many, too few.

Not for perfection though that is a part of it.

The pressure of silence is about me.

A commotion.

"History

surprise us!" is one petition.

"Society

save us!" is one petition.

Speeding the lizard.

Thingbedded mutterings delay. [...]

A man in Klapmuts breathes the secret.

And a shack on the coast is disputed.

The nervous system ails the stars.

You leapt clothed into the river in spontaneous love for me. (Collected Poems 78-9)

Unable to explain exactly why, in certain poems, he separated each line by a double space-perhaps to see each thing, each observation, each action, separately and distinctly—Clouts did 'explain' the final line: "I was walking near a river in Stellenbosch with a girl I loved very much and she jumped into the river in her clothes [...]. And she said, 'That's how I feel"' ("Sydney Clouts speaking" 22).

If such an aside is meant to endorse Clouts's comment, above, that the imagination disestablishes its own constructions continually, then the interpreter (in this case, Wylie) is not given much help from the poet. Rather, Wylie must proceed according to his own phenomenological dictum to discern that the "central philosophical problematic" of Clouts's poetry- "the relationship between mind, word, and object" (119) - is the style of the poem, is the meaning of the poem. I paraphrase Wylie (193-200): First, a rigorous attentiveness: one does not see or watch the land; one performs a 'vigil', one enters the "quick grain", one "dwells" in the Heideggerian sense of inhabiting the earth, poetically, almost jealously, when both existential and political annihilations loom. Despite, or because of, such 'in-dwelling', the poet is conscious of the "stupid[ity]" (Wylie 197) of the petty locality and selfish goal of so much conflict ("And a shack on the coast is disputed"); conscious of the hapless appeals that 
the public makes to the abstractions of History and Society, neither of which exists independently of individual choice and behaviour, neither of which is capable of surprising or saving anyone. Outside the artefact of the poem, nevertheless, Clouts wants answers:

$[\ldots]$ we ask either for revelation, or we ask for leadership, or 'the message'. We are so feeble we look to sociologists to solve our problems, so feeble that we want historians to tell us the meaning of culture [...]. I think that the anxieties which come to society are anxieties for which there doesn't seem to be any collective answer at all. ("BBC broadcast" 142)

In the end, as in "Residuum", life is mystery; in the end, words are the instruments of sensation, sensation is transcendence: "No lexicon, just one word accommodates us, quickly said. / No word is my dwelling place". Rather, "I am the method of the speck and the fleck".

One gets Clouts's gist, the gist that Wylie unenviably has to try to convert to the limited language of literary commentary: "The work is the thing" (M. Clouts qtd in Wylie ix). One realises also that in drawing attention to Clouts's apparent dismissal of the value of sociological or historical intervention, both inside and outside the poem, Wylie has inadvertently provided detractors with the ammunition to marginalise Clouts in a South Africa of the political imperative. ${ }^{2}$ In this country, people are killed in disputes about a shack on the coast, or a shack anywhere else.

\section{"Intimate lightning"}

The focus on Clouts's poems of the "speck and the fleck", together with his observations on poetry, presents unique insights, but - as I suggested at the outset—can curtail alternative possibilities in the reading of the poetry. Whereas Wylie sees Clouts and things in interfusion, I see Clouts and things as independent entities. A comparison of our respective responses to "After the poem", reproduced below, might illustrate the distinction:

After the poem the coastline took

its place with a forward look

toughly disputing the right of a poem to possess it

It was not a coast that couldn't yet be made

the subject of a poem don't mistake me

nothing to do with 'literary history'

But the coast flashed up-flashed, say, like objections

up to the rocky summit of the Sentinel

that sloped into the sea

such force in it that every line was broken

and the sea came by

the breaking sea came by

(Collected Poems 75)

In his study Wylie includes my earlier response to this poem:

The assertiveness of the opening lines (accentuated in the monosyllabic rhyming words, "took/look"); the plosive 'p' sounds ("toughly disputing the right of the poem to possess it"); the 'broken' lines; and the roll of defiance in the concluding couplet-such energy of language and rhythm underscores the idea of the 'self-assertiveness' of independent things (for the coastline resists being pressed into the service of the poem). As a result, the poet is denied the comfort of complicity with phenomena: the natural surroundings resist appropriation to the needs of a human universe. Yet, it is through this failure to 'possess' the coast that Clouts's poem remains true to its own intellectual and aesthetic principles: by admitting that the artefact has no dominion over entities, he proclaims the self-sufficiency of each thing, including his poem. (Chapman 166 qtd in Wylie 100) 
While he concurs with most of what I said, Wylie contends that:

those words, "complicity" and "failure" speak of guarded praise [...]. The poet is admitting the independence of words and objects only up to a point. Or in one mode; in another mode, they are indeed complicit, in the sense that the word's origin in Latin is plicare, to fold. Word, mind, and sea are folded into one another, and the structure of the poem embodies this [...]. What the poem deconstructs is the very notion that word and world are inevitably distinct; it enacts not an either/or dichotomy so much as a both/and symbiosis, enfolding within a single movement of renewal or upgraded consciousness [...] (101)

Our differences could strike the reader as nitpicking, but whether the poet enters the thing or retains his independence of the thing can have consequences for the attention one is prepared to grant one poem or another. Basically, I wish to free Clouts somewhat from his 'enfoldedness' in things, thus granting him a greater freedom to interact with a world of human beings. I end up, in consequence, finding key poems where Wylie evidently does not, at least judging by the limited space he accords poems such as "Is" (the story of the biblical Job given existential purchase in the subtropics), "Idiot child" (a father's agonising process of attachment to the child of the poem's title), and, as I shall proceed to discuss, "Epic" and "Folktales". These poems all resist quick transmutations into analogies of perception (as in the poems of $16^{\text {th }}$-century Portuguese voyaging) or in poems of "old and strange characters" such as "The street hawker and his barrow" (Collected Poems 48), a poem which, to quote Wylie, is "arguably less concerned with the hawker as an individual than with outlining the larger dynamics that have marginalised him" (154). Rather, we encounter in "Is", "Idiot child", "Epic", and "Folktales" abbreviated narratives, in which objects occupy a subsidiary presence to people.

In "Epic" the two heroes, Metaphor and Metaphysics—as their names suggest — can be expected to exemplify the human tendency to devise analogical schemas to confer shape on randomness or the absurd: "Metaphor and Metaphysics / two old men [...] In the long barn of life we have turned over/and sleep on the streaked straw" (Collected Poems 67). Any ambition that the pair-the knower and the known-might have had to impose systems and designs upon the world is ignominiously thwarted. Yet a new form emerges, anti-heroic and colloquial, as appropriate to the rough-and-tumble of everyday life. It is a mundanity that is too often excluded from Wylie's response to Clouts's poetry.

As in "Epic", "Folktales" pursues the paradox in a foreshortened narrative of how formal poetics (a system) can be the marshalled against systems that are inimical to new searches for meaning, that is, for fresh consciousness. The protagonist, Nimbilo, the nameless scholar, has subjected reality to 'interpretation', only to find himself entrapped in the monotony of his own terminology:

looking out of lakes

in his research

the arithmetical

and grew

the geometrical

the grammatical the economic

the political

and the theological (Collected Poems 110)

In attempting to sever his attachment to his secure existence, this nameless scholar seeks the 'darkness' which, as far as he is concerned, is synonymous with the adventure of the forest. But habit being too firmly ingrained, he discovers that he cannot for any length of time escape the 'light' of systemised knowledge:

the forest's utmost shinings caught

his whispers as he moved far off within it

to the hut that he had heard of, saying

consciously, "O earth, O aarde",

he himself, and he, yes even he

gathered or shook the leaves with a sigh

as he approached the light beneath the door. (111)

Playing upon folktale motifs of voyaging and discovery, Clouts implies that the darkness is the true mystery; that regulated living, in contrast, may lead to 'mystification', to the enclosure of phenomena within an explanatory 
theory (suggested here by the "light beneath the door") which, despite Nimbilo's sigh, Wylie sees as "welcoming light".

Continuing to look outwards, I interpret the key poem "Intimate lightning" quite differently to Wylie, a key poem in that it is this poem that provides the title of the study. With references to colonial trade in Africa, the poem, in retrospect, may be seen to invoke the by now familiar 'postcolonial' Achebe/Conrad contretemps about European racism in Africa:

Too succulent for quinces comes

this fresh quo vadis,

Africa

the bud

the blossom

the scent

of intimate lightning

Tusks traded for cash somewhere staling under hessian,

to be fetched for another buyer at the coast.

Tusks, skins, rhinoceros horn. (Collected Poems 69) ${ }^{3}$

Alert to the fact that Clouts, "like so many white settlers and their descendants could not think of himself as African in any systematic or untroubled sense" (183-4), Wylie pursues interpretation that is consistent with his primary assumption of Clouts's poetics as an interfusion of the poet and the thing, thus 'opening up' newness:

What I want, Zambezi's

abler darkness fools with:

the full penetrant

eye, and more, much more:

eye in whose obstinate tusks and rains

the forest opens;

truth of my long lianas tense with dew. (69)

This explorer, in Wylie's reading of the poem, discovers ephemeral, but vividly detailed, truths. In contrast, my own reading - as Wylie notes (185) — has Clouts debunking the myth of the white explorer and the shabby, hubristic motives of the European civilising mission. So intent is Clouts's explorer (a parody of Conrad's Kurtz?) to discover a higher justification for his venture that he fails to see not only the consequence of colonial corruption, but also the newness of his immediate surrounds. Instead of sensing the "intimate lighting" - the wonder of presence, or, as Wylie phrases it, "the unkempt but insecure wealth within" (112) - the explorer in the narrative of the poem frustrates himself by searching for what is not there. By being true to itself, Africa defeats another intruder, whose cry of aggrieved expectation echoes down the river. Tucked into his scooped log (his ambition sitting awkwardly about him), Clouts's explorer sails despairingly into his own heart of darkness:

It promised these

Once, but lost them

In me. I

Now, in a scooped log, ride

Upon More, More, the River of Night. (69)

I offer my 'alternative' reading of "Intimate lightning" not to dispute the appropriateness of Wylie's focus on Clouts's phenomenological attentiveness, but to situate the poet a little more firmly than Wylie does as a 'live' voice in current literary discussion. An explorer who, in Africa, finds the light of truth is perhaps less 'relevant' to the South than an explorer who, as I read the poem, is left baffled by an Africa that thwarts his penetrant (European) eye. 


\section{'Silent decade'}

We are left with the issue of Clouts's relative obscurity. It is an issue that raises several subsidiary issues, most of which, as Wylie enumerates ( $\mathrm{xv}-\mathrm{xvi}$ ), would have been beyond Clouts's control: only a small number of people in South Africa might be said to belong to a rich "reading culture", poetry is badly taught in schools and universities where it remains the poor cousin of fiction, little magazines struggle to survive, newspaper reviewing rarely exceeds the length of a blurb. English, although the lingua franca, is the first language of merely ten percent of the South African population. Whereas Afrikaans publishing has a small but focused readership, English-language output competes with the power of publishing dissemination from the larger English-speaking world.

Clouts had a small output of published poetry and, although unhappy in England while missing the landscape and tang of the Cape, he spent most of his writing life outside of South Africa. At the same time, his close association with the Department of English at Rhodes University has earned him a solipsistic reputation as a 'Grahamstown' poet, as Stephen Gray unkindly put it in a review in the Johannesburg daily, The Star (10 September 1985), "Notably his loyal friends in Grahamstown [...] took his silence [after the publication of One Life] for truth. His status as the guru of the private archetype of poetry grew out of all proportion" (qtd in Wylie xvi-xvii). Wylie, a member of the Rhodes University English Department, has sought to right such a view.

In addition to all this, there is the political dynamic of the 1960s. It is a decade that has come to be called the 'silent decade': a decade of draconian apartheid legislation, in which the state sought to crush all opposition to its segregationist policies, including the gaoling of opposition leaders (for example, Nelson Mandela) and the banning of anti-apartheid political organisations. On the cultural front it is crucial to recollect that the Publications Control Board was instituted in 1963 and that 'avant-garde' Afrikaans literary expression and commentary found it difficult to be heard in the established literary journals, including Tydskrif vir Letterkunde. Writers resorted to 'little magazine' ventures. Sestiger, launched in 1963, lasted for only three years. The English-language equivalent, Contrast, would continue with a slight change of title to the present day while a poetry magazine, New Coin (first edition, 1964), was an outcome of Butler's energetic commitment to the local scene. In 1962 A. P. Grové and C. J. D, Harvey - with the assistance of Butler-compiled and edited the 300-page anthology, Afrikaans Poems with English Translations, while a certain displeasure in 'official' Afrikaans circles accompanied the decision to award the Hertzog Prize for Literature to the Sestiger novelist, Etienne Leroux for Sewe dae by die Silbersteins. With English perceived to be under threat by Afrikaner-state nationalism, the English Academy of Southern Africa emerged in the 1960s.

It would seem that the decade was hardly conducive to a flourishing literary scene. Yet, the years produced writers of considerable calibre such as Athol Fugard, André Brink, Etienne Leroux, Alex La Guma, and several affiliated to Drum magazine, including Es'kia (then, Ezekiel) Mphahlele, Bloke Modisane, and Can Themba, all of whom were staunch critics of state principles and actions. But to confine my overview to poetry, if Clouts-as Wylie concludes-is the finest poet of his generation, then he has formidable competition, if competition is the appropriate word. Rather, Clouts may be seen to join an array of formidable voices. As I said, I cannot do justice to the entire literary scene of the decade, but I can sketch a landscape for ongoing consideration.

Two significant figures, both of whom Clouts admired, foreshadow the decade: Roy Campbell-“I saw blue thunder when I read Campbell" ("Sydney Clouts speaking" 10) and N. P. van Wyk Louw—"a fullness of sound often sounding spare simply because it is so functional [...] brute wisdom, or brute finesse, which produces tension, mystery, sometimes darkness" ("Letter to Ruth Harnett"). If these two poets ensured that poetry from this country entered the high art of modern expression and technique, then D. J. Opperman and Peter Blum also figure notably at the start of the decade. Whether consciously or not, Clouts entitled one of his poems after Blum's "Wat die hart van vol is" (Collected Poems 118). Blum's earlier poem of that title, in the 1955 collection Steenbok tot poolsee, adapted Renaissance and early scientific allusion to the locality of the Cape, including the 'Kaaps' dialect of some of the 'Coloured' people. (As I have said, Clouts would attempt, unsuccessfully in my view, to imitate 'Kaaps' speech in his "Hotknife" sequence of poems.) In Clouts's "Wat die hart ..."-a strangely despairing poem for him - the splendours of Western civilisation (including its Renaissance paintings) are susceptible to what he seems to suggest is the genetically coded violence of the human species.

The decade draws to a close with Opperman's 1970 collection Edms Bpk, in which, in "Vele woninge", Opperman pays tribute to abilities which he sought to emulate: Van Wyk Louw's skill in ringing the changes of style and temper in collection after collection. Earlier Opperman, in 1963's Dolosse, had penned the tribute to another poet whom he admired, "By die dood van Roy Campbell" (On the death of Roy Campbell). Indeed, the years of the 1960s saw Opperman shift from a confessional mode to a more 'mixed' style that was open to the complexities of 
living outside of a Western-European high tradition of literature, as did the Sestigers: those writers of the Sixties, some living in Paris, who adapted French existentialism, surrealism, and modernist experiments with form to new, 'anti-establishment' voices in Afrikaans literature. Breyten Breytenbach's first collection, Die ysterkoei moet sweet (1964), found affinities with both the surreal manner and Bertolt Brecht's Marxist-modernism. In Kouevuur (1969) he continued to add richness, subtlety, and flexibility to an Afrikaans literary language while prompting the Afrikaner to allow a racist self to die in the search for a true humanity.

If instability of belonging characterises the Sestigers, Douglas Livingstone's first substantial collection in 1964, Sjambok and Other Poems from Africa, turned from the plain-speaking voices of a previous generation of English-speaking poets, most notably in Butler and Anthony Delius. Adopting a 'modernist' elevation of a-logical sequence above a grammar of causality, Sjambok signalled a radical alertness to the 'wind of change' in southern Africa. Eschewing the fictive mode, the political-activist poetry of Dennis Brutus (statement-like lines infused with romantic undertones) first appeared in 1962's Sirens, Knuckles, Boots. As a mentee of Brutus, the younger 'Coloured' poet, Arthur Nortje, began producing experimental, daring, and ambiguous poems on the pain of exile, poems that would be collected posthumously as Dead Roots in 1972. In a mingling of styles-from 'Kaaps' to African American spirituals and jazz-Adam Small asserted the 'Self' against official Afrikaans while later, in 1975's Black Bronze Beautiful, he would translate into English a selection of Van Wyk Louw's poetry.

The decade witnessed, too, a dramatic shift in women's voices from the quieter poetry of Elizabeth Eybers to the free verse, abrupt juxtapositions, and erotic power of Ingrid Jonker (Rook en Oker, 1963). At the same time, Jonker's contemporary, Ruth Miller, pursued the depths of psychological alienation and the challenge of writing creatively about illness and death (Floating Island, 1965; Selected Poems, 1968). Both poets reached beyond the locality to find resonance with a poetry of intensity abroad, particularly in Sylvia Plath and Anne Sexton.

The last years of the decade heard the first sounds in Oswald Mtshali and Mongane Wally Serote of the Black Consciousness voices of the 1970s. The 1960s, in contrast, were less about white/black politics and more about anti-nationalistic, 'dissident' voices seeking to heal division between whites and whites: that is, between Afrikaans and English-speaking South Africans. In this light, we may note, as Wylie does, Clouts's forays into the climate of the decade. His "Roy Kloof" poems have the protagonist, the son of an Afrikaans father and an English mother, lamenting divisions of "rock" and "shire" (Collected Poems 74). More substantially, we have two sardonic portraits: one of racist-patriarchal power in "For the thunder"- "the blacks bring in the harvest: he [the farmer] endures the truth of movement, but he can shoot" (Collected Poems 101), the other, "Professor Gulf", in which the persona of the poem ironically echoes the Verwoerdian euphemism of separate development- "Nation is separate nation forever [...] a system/guaranteeing good government" (Collected Poems 126-7).

Opposition among writers to a repressive political climate sometimes took obvious forms, as in Brutus's explicit poetry of protest. More often in literary circles, however, thought and language resistance took more implicit or indirect forms. It was not a 'resistance' that would, or will, satisfy the political demand but, as Livingstone would subsequently phrase it: "I find that the range, resonance and sinewy-ness of language is a major civilising force" (11). Whether in his more inward-looking poems or his more outward-looking poems, Clouts can be seen to share Livingstone's sentiment. In fact, I invoke Livingstone as a prompt to reflect on whether Clouts has been 'buried' in any greater depth than many deserving poets. Livingstone has a wider range than Clouts and continued to develop and publish up until shortly before his death in the 1990s. Yet only his first two collections, the second in 1970, were published outside of this country: an obstacle to his poetry having attained the world reach that it deserved. (An even greater obstacle to wider dissemination, of course, involves poetry that requires to be translated into the global lingua franca of English.)

Like Livingstone, nonetheless, Clouts is well represented where most readers will go to read poetry-to the anthologies. Clouts appears in Butler's A Book of South African Verse (1959), Cope and Krige's The Penguin Book of South African Verse (1968), Butler and Mann's A New Book of South African Verse in English (1979), Chapman's A Century of South African Poetry (1981), and Chapman's The New Century of South African Poetry (2002; 2018). Admittedly, Clouts is represented by more poems in my 1981 anthology than in the anthologies of 2002 and 2018. But, then, so are many other poets. Publishing costs dictate that anthologies remain at a certain page length; as the years go by, new poets appear and deserve to be anthologised. 


\section{Conclusion}

Like the poetry to which I have referred above, Clouts's poetry was a long way from the noise of the governing National Party in the silent decade, where the swart gevaar (black danger or peril) was seen as the Communist onslaught on white Christian civilisation. By the same token, his poetry is a long way from the clichés and catchphrases of the current political scene, whether of comrades, cadres, or collective leadership. The more variegated times of today might be more conducive to Clouts's poetic world than the times, in the 1960s, in which One Life appeared or the times, in 'struggle years' of the 1980s in South Africa, which saw the posthumous publication of his Collected Poems.

To return to Wylie's study, the question of whether Clouts is the finest poet of his generation is not perhaps the primary question to be pursued. Intimate Lightning achieves the primary purpose of what it sets out to do. It provokes consideration, or reconsideration, of its subject: its subject being, inseparably, Clouts and the challenges of poetry as a form, a style, an intention, and an ambition. In such consideration, Sydney Clouts emerges from the pages of Dan Wylie's study as what he is: a poet quite unlike any other we will encounter.

\section{Notes}

1. '[...] my meaning is, that the poet has not a 'personality' to express, but a particular medium [...]. The emotion of art is impersonal" (Eliot 299-301).

2. See, for example, the negative responses to Clouts of Glenn, Joubert, and Watson.

3. According to Achebe, "Conrad was a thoroughgoing racist" (13).

4. The title is derived from the Afrikaans epigram, "Wat die hart van vol is, loop die mond van oor" (The mouth overflows with the perceptions of the heart).

\section{Works Cited}

Achebe, Chinua. Hopes and Impediments: Selected Essays 1965-87. Heinemann, 1988.

Barbaras, Renaud. The Being of the Phenomenon: Merlieu-Ponty's Ontology, translated by T. Toadvine \& L. Lawlor. Indiana U P, 2004.

Bloom, Harold. The Anxiety of Influence. Oxford U P, 1973.

Butler, Guy. "On Sydney Clouts." English in Africa, vol. 11, no. 2, 1984, pp. 81-107.

Chapman, Michael. South African English Poetry: A Modern Perspective. Ad Donker, 1984.

Clouts, Margery. "Letter to Guy Butler." 12 March 1994. 2007, 17. 2. 42. National English Literary Museum, Grahamstown.

Clouts, Sydney. "A country whose mediocrity ..." n. d. 94.1.12.5. National English Literary Museum, Grahamstown. .BBC broadcast." Collected Poems. David Philip, 1984, pp. 141-3.

. Collected Poems, edited by M. Clouts \& C. Clouts. David Philip, 1984.

"Letter to Ruth Harnett." 29 June 1966. 2008, 48.1.1.1,1,2,3. National English Literary Museum, Grahamstown.

. "Notes for poetry." English in Africa vol. 11, no. 2, 1984, p. 37.

One Life. Parnell \& Sons, 1966.

"Sydney Clouts speaking about his poetry, 1 \& 2." English in Africa vol. 11, no. 2, 1984, pp. 7-24.

$\overline{\text { Eliot, }}$ T. S. "Tradition and the individual talent." English Critical Texts, edited by D. J. Enright \& E. De Chickera. Oxford U P, 1962, pp. 293-301.

Glenn, Ian. "Sydney Clouts: Our Pen-insular Poet." English Academy Review vol. 3, no. 1, 1985, pp. 127-34. DOI: https://doi. org $/ 10.1080 / 10131758585310101$.

Harnett, Ruth. "Some poems by Sydney Clouts." English in Africa vol. 11, no. 2, 1984, pp. 108-61.

Joubert, Susan. "The unresolved shibboleth: Sydney Clouts and the problems of an African poetry." Theoria vol. 75, 1990, pp. $87-106$.

Livingstone, Douglas. “Casanova in modern dress." Frontline Books: The South African Review of Literature, no. 3, 1983, pp. 9-11.

Watson, Stephen. "Sydney Clouts and the limits of romanticism." World Literature Written in English vol. 28, no. 2, 1998, pp. 210-32. DOI: https://doi.org/10.1080/17449858808589060.

Wylie, Dan. Intimate Lightning. Sydney Clouts: Poet. Unisa, 2018. 